\title{
FUEL CYCLE COSTS FOR HEAVY WATER REACTORS
}

C. H. Bloomster

JUNE 24, 1968

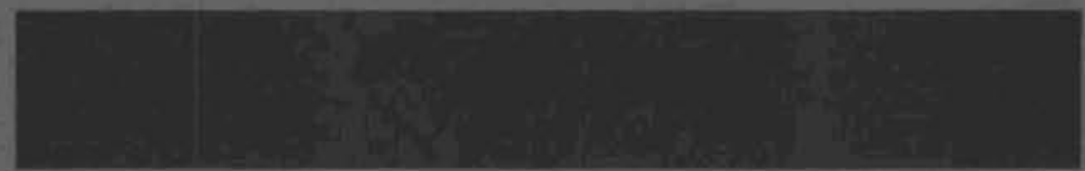

\section{AEC RESEARCH \& DEVELOPMENT REPORT}

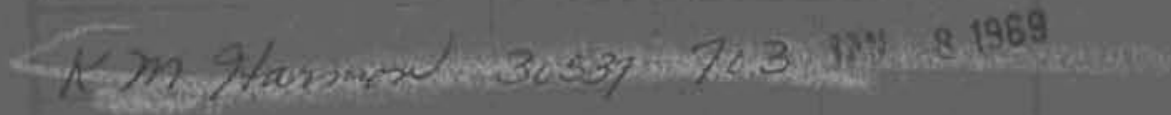




\section{LEGAL NOTICE}

This report was prepared as an account of Government sponsored work. Neither the United States. nar the Commission, nor any persan octing on behalf of the Commissioni

A. Mokes any warranty or represtentafion, expressed or implied, with respect to the acsuracy, completeness, or usefulness of the information conteined in this teport, or that the use of any information. opparatus, method, or process disclosed in this repoit may not infringe privately owned rights or

B. Assumes any liabilities with respect ta the vie of, ot for damages resulting from the use of any information, apparatus, method, or process disclosed in this seport.

As used in the obove, "person octing on behalf of the Commission" includes any emplayee of contractor of the Commission, or employee of such contractor, to the extent that such employee or contractor of the Commission, or employee of such controctor prepares, dissaminates, or provides access to, any information pursuant to his employment or contract with the Commission, or his employment with such contractor.

\section{PACIFIC NORTHWEST LABORATORY}

MICHLAND, WASHINGTON

operated by

BATIELLE MEMORIAL INSTITUTE

for the

UNITED STATES ATOMIC ENERGY COMMISSION UNDER CONIRACT AT(45-1)-1830 


\section{1}

BNWL-833

UC-80, Reactor Technology

FUEL CYCLE COSTS FOR HEAVY WATER REACTORS

By

C. H. Bloomster

Fuel Cycle Analysis

Advanced Concepts and Analysis

Mathematics Department

June 24, 1968

그. 342468

PACIFIC NORTHWEST LABORATORY

RICHLAND, WASHINGTON 
Printed in the United States of America Available from

Clearinghouse for Federal Scientific and Technical Information National Bureau of Standards, U.S. Department of Commerce Springfield, Virginia 22151

Price: Printed Copy $\$ 3.00$; Microfiche $\$ 0.65$ 
FUEL CYCLE COSTS FOR HEAVY WATER REACTORS

C. H. Bloomster

\section{ABSTRACT}

The effect of important economic and fuel design parameters on fuel cycle costs was calculated for a simulated 1000 MWe HWR based on the Pickering reactor and fuel design. 


\section{TABLE OF CONTENTS}

$\underline{\text { Page }}$

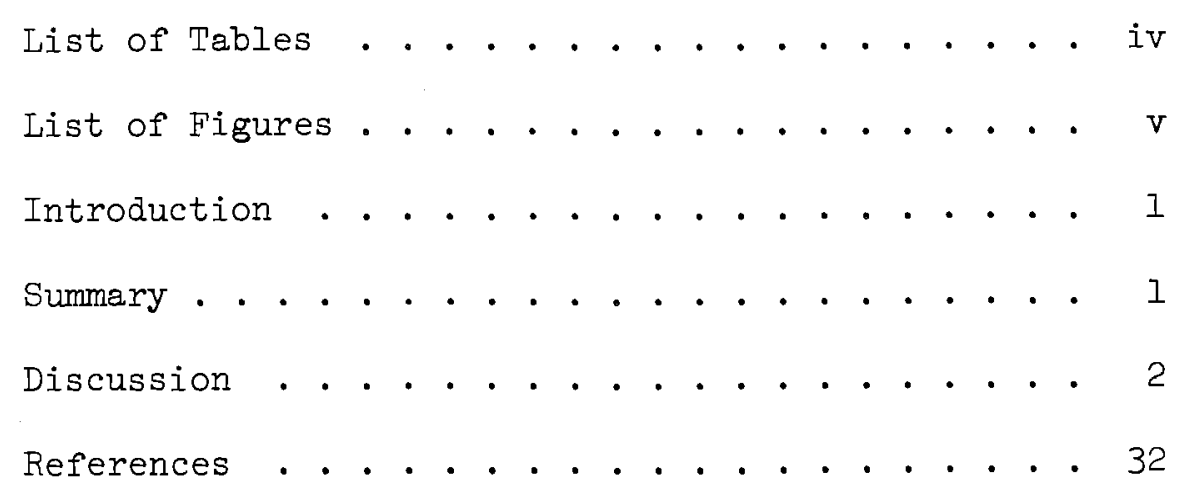




\section{LIST OF TABLES}

Table

Page

Parametric Values for Base Case

7

II Effect of Various Parameters on Fuel Cycle Costs

III Change in Each Parameter Required to Cause a $0.1 \mathrm{mill} / \mathrm{kwhr}$ Change in Fuel Cycle Cost

IV Optimum Lattice and Enrichment Calculated for Different Values of Several Important Fuel

Cycle Cost Parameters 


\section{LIST OF FIGURES}

Figure

Page

1 Typical Fuel Cost Data as a Function of Fuel Exposure

2 Effect of Lattice Size on $\mathrm{D}_{2} \mathrm{O}$ Costs

3 Optimization of Moderator to Fuel Ratio and Fuel Exposure

4 Effect of Electrical Conversion Efficiency on Fuel Cycle Cost

5 Effect of Pressure Tube Thickness on Fuel Cycle Cost

6 Effect of $\mathrm{D}_{2} \mathrm{O}$ Purity on Fuel Cycle Cost

7 Effect of Plutonium Price on Fuel Cycle Cost for Two Reprocessing Costs

8 Effect of Reprocessing Cost on Fuel Cycle Cost for Two Plutonium Prices

9 Effect of Fabrication Cost on Fuel Cycle Cost

10 Effect of $\mathrm{D}_{2} \mathrm{O}$ Interest Rate on Fuel Cycle Cost

12 Effect of Separative Duty on Fuel Cycle Cost

13 Effect of $\mathrm{D}_{2} \mathrm{O}$ Losses on Fuel Cycle Cost

14 Effect of Working Capital Interest Rates on Fuel Cycle Cost

15 Effect of Fuel Inventory Interest Rate on Fuel Cycle Costs

16 Combined Effect of Interest Rates on Fuel Cycle Costs

17 Effect of $\mathrm{U}_{3} \mathrm{O}_{8}$ Price on Fuel Cycle Cost 29

18 Effect of Specific Power on Fuel Cycle Cost 30

19 Relationship Between Enrichment and Exposure for Five Moderator to Fuel Ratios 
FUEL CYCLE COSTS FOR HEAVY WATER REACTORS

\author{
C. H. Bloomster
}

\title{
INTRODUCTION
}

This report describes the effect of several important economic and fuel design parameters on the fuel cycle costs of a heavy water reactor. Heavy water reactors, which have high conversion ratios, occupy a position intermediate between present light water reactors, "burners", and fast reactors, "breeders". Under certain economic conditions heavy water reactors have the potential to become the lowest cost power producers. Fuel cycle costs were calculated for a simulated 1000 MWe heavy water reactor based on the Pickering reactor and fuel design. (I) Pickering is a pressure-tube reactor, $\mathrm{D}_{2} \mathrm{O}$ cooled and moderated. The fuel element is a zirconium clad, $\mathrm{UO}_{2}, 28-\mathrm{rod}$ bundle.

The purpose of the study was to determine the leverage of each parameter in two distinct economic environments in which (1) enriched uranium may be used, and (2) enriched uranium is prohibited. In addition, the study was to provide a measure of the benefits which would accrue from various design improvements, and thus aid in the formation of 'research and development programs. This study was sponsored by the Heavy Water Reactor Program Office of the USAEC.

The fuel cycle costs were calculated using the Battelle-Northwest (BNW) FULCYC code. The FULCYC Code ${ }^{(2)}$ is a system of chained computer codes for reactor fuel cycle analysis, employing burnup, economic, and optimization calculations.

\section{SUMMARY}

Fuel cycle costs were calculated for a simulated 1000 MWe heavy water reactor, and the effect of several important economic and fuel design parameters was determined. The best potential for fuel cycle cost improvement appears to be in increases in the electrical conversion efficiency obtained through higher coolant temperatures and pressures, and made possible by thicker or stronger pressure tubes. Since optimum fuel exposures in heavy water reactors are lower than in light water reactors, higher 
coolant temperatures should be less deleterious from both the hydriding and cladding strain standpoint in heavy water reactors than in light water reactors.

In general, within the range of the parameters studied, minimum fuel cycle costs occurred with fuel exposures between 18,000 and 22,000 MWD/T, enrichments between 1.0 and $1.5 \% \mathrm{U}^{235}$, and $\mathrm{D} / \mathrm{U}$ atom ratios (moderator to fuel) between 20 and 40 .

\section{DISCUSSION}

The minimum fuel cycle cost is an important concept, for it provides a. common basis for comparing different fuel cycles. One of the FULCYC codes, called MINIMIZER, ${ }^{(3)}$ determines the minimum fuel cycle cost under a given set of conditions. The minimum fuel cycle cost is determined from a series of independent calculations of reactivity limited fuel exposures. Under reactivity limited conditions, the initial fuel enrichment determines the maximum fuel exposure. In general, some cost components of the fuel cycle increase with exposure, e.g., inventory costs related to enrichment, and others decrease, e.g., fabrication and reprocessing costs, such that a minimum fuel cycle cost exists at a certain exposure (Figure 1 ) depending on the extant economic parameters.

In a heavy water moderated reactor, the moderator-to-fuel ratio $(D / U)$ has a significant effect on the fuel cycle costs through its influence on reactivity and the $\mathrm{D}_{2} \mathrm{O}$ loss and inventory cost. Some costs increase with the moderator-to-fuel ratio (Figure 2) and others decrease; a minimum fuel cycle cost exists at the optimum moderator-to-fuel ratio and fuel exposure. Figure 3 illustrates the three-dimensional minimization made by FULCYC to obtain the optimum moderator-to-fuel ratio, fuel exposure, and minimum fuel cycle cost.

Equilibrium fuel cycle costs were calculated for three cases: (1) the Pickering lattice using natural $\mathrm{UO}_{2}$, (2) the Pickering lattice optimized on enrichment, and (3) the Pickering fuel design optimized for both lattice (moderator-to-fuel ratio) and enrichment. Each parameter was varied independently from the base value (Table I), while the other parameters 
remained constant. The corresponding change in the minimum fuel cycle cost for a given change in each parameter was calculated for the three cases (Table II). Inversely, the change in each parameter required to cause a $0.1 \mathrm{mill} / \mathrm{kwhr}$ change in fuel cycle cost is shown in Table III. The net effect of several simultaneous changes in parameters are additive in the Pickering natural $\mathrm{UO}_{2}$ case since there are no changes in enrichment or lattice, but are not necessarily additive in the other cases for partially off-setting changes in enrichment or lattice may occur.

The variation in minimum fuel cycle costs with each parameter is shown graphically in Figures 4-18. The identification symbols are consistent for all figures. In general, the same vertical scale is used for each figure, and the horizontal scale extends from zero to twice the base case value. Exceptions are made in those parameters in which large variations are atypical, i.e., electrical efficiency, $\mathrm{D}_{2} \mathrm{O}$ purity, and pressure tube thickness. The fuel cycle cost includes loss and inventory charges attributable to the $\mathrm{D}_{2} \mathrm{O}$ coolant and moderator, but does not include costs attributable to $D_{2} \mathrm{O}$ in the reflector or heat exchange system. Some of the conclusions which may be drawn from the data are described in the following paragraphs.

Although the electrical efficiency has a relatively large effect on fuel cycle costs (Figure 4), the effect extends throughout the entire power cost calculation affecting directly both the capital and operating cost components. Thus the effect of electrical efficiency on power costs is much larger and more pervasive than is seen in Figure 4. For instance, an increase in the electrical conversion efficiency to $34 \%$, which is projected for future light water reactors, from $29 \%$ would decrease power generation costs by $0.6-0.9$ mills $/ \mathrm{kwhr}$.

The thickness of the pressure tube (Figure 5) has a much greater effect on fuel cycle cost in the natural uranium system than in the enriched uranium systems, in which the increased neutron absorption can be counteracted with slight increases in enrichment. In contrast, in the natural uranium case the fuel exposure is significantly lowered. An increase in the pressure tube thickness in the enriched uranium systems affords the opportunity to increase the coolant temperature and pressure 
and thus increase the electrical conversion efficiency. Since the electricai conversion effliciency has a relativeiy large effect on power costs compared to pressure tube thiskness, a slibstantial net reduction in total power cost is possibie if other cost increases are not offsetting. Other costs, which would probably increase, are material costs for the pressure tube, inventory costs for added $\mathrm{D}_{2} \mathrm{O}$ in the heat exchange system, $\mathrm{D}_{2} \mathrm{O}$ losses, and the capital costs for the heat exchanger. The fuel problems associated with higher coolant uemperatures, ciadding hydriding, strain, and consusion, sinclid be iess formidable in heavy water reactors than in light water reactors since fuel exposures in heavy water reactors are typicaliy lower. Other than a thioker pressure tube, similar improvements in power costs might be cotalned through the substitution of a stronger material for the pressure tube provided that the neutron absorption of the material was not too great. A Zr-Nb alloy has been suggested for this appilcation.

The $\mathrm{D}_{2} \mathrm{O}$ purity (Figure 5) has an influence on fuel cycle costs similar to pressure tube thickiness. The $\mathrm{D}_{2} \mathrm{O}$ purity is measured by the amount of $\mathrm{H}_{\bar{L}} \mathrm{O}$ impurity. The $\mathrm{H}_{<} \mathrm{O}$ impurlty zauses an Increase in the neutron $\mathrm{ab}-$ sorption rate which increases fiei cycie costs, The increase in costs is greater in the naturai wranjum system than in the enriched uranium system because the fuel exposure, as with the thicker pressure tube, is lowered significantly. Increased neutzon absorption, or poisoning, favors higher D/U ratios.

The effect on fuel cycie costs of piutonium prices and reprocessing cost is interdsperident. The effect of platonium price is shown for two separate reprocessing sosts : Figure 7 ; and the effect, of reprocessing cost is shown tor two separate piutonium prices (Figure 8). The horizontal lines in each figure represent the range in which the throw-away fuel cycle is economic. Over this range the fissile values in the irradiated fuel are less than the cost of reprocessing. For instance, for the Pickering reactor using naturai Uui, the throw-away cycle is economic below fissile plutonium values of $\$ 13 / \mathrm{g}$ with a reprocessing cost of $\$ 37 / \mathrm{kg}$, but the throw-away cycle is economic only below fissile plutonium values of $\$ 3 / \mathrm{g}$ with a reprocessing cost of $\$ \mathrm{LO} / \mathrm{kg}$. Similarly with varying reprocessing costs (Figure 8 ), with fissile plutonium at $\$ 10 / g$, the throw-away 
cycle is economic when reprocessing costs exceed $\$ 30 / \mathrm{kg}$ (in the natural $\mathrm{UO}_{2}$ case), but with fissile plutonium at $\$ 20 / \mathrm{g}$ the throw-away cycle is economic only when reprocessing costs exceed $\$ 50 / \mathrm{kg}$. As a rule of thumb applying to these base conditions, the throw-away cycle is more economic whenever the reprocessing costs, expressed in $\$ / \mathrm{kg}$, exceed the fissile plutonium value, expressed in $\$ / g$, by a factor of 3 .

Increasing fabrication cost has a much greater effect on fuel cycle cost for the natural uranium case than for the enriched uranium cases (Figure 9) for the higher fabrication costs can be partially offset through increases in enrichment and fuel exposure. Conversely, as fabrication costs decrease, the optimum fuel exposure and enrichment decrease, approaching natural uranium at very low fabrication costs.

Interest rate on $\mathrm{D}_{2} \mathrm{O}$ affects the choice of lattice pitch, as may be inferred from Figure 10 in which fuel cycle costs diverge with higher interest rates between the Pickering lattice with optimum enrichment case and the optimum lattice and enrichment case. At higher interest rates, tighter lattices, i.e., lower $\mathrm{D} / \mathrm{U}$ ratios, and higher enrichments are optimum; at lower interest rates, higher $D / U$ ratios and lower enrichments are more economic. Thus public power with lower interest rates would tend to favor higher $D / U$ ratios than private power, other things being equal.

The effect of the $D_{2} \mathrm{O}$ cost (Figure 11 ) is similar to the effect of the interest rate on $\mathrm{D}_{2} \mathrm{O}$. Decreasing $\mathrm{D}_{2} \mathrm{O}$ costs favor larger lattices and lower fuel enrichments.

Separative duty (Figure 12) has the opposite effect from the $\mathrm{D}_{2} \mathrm{O}$ cost. Higher separative duty favors lower enrichment, approaching natural enrichment only at prohibitively high separative duties.

The effect of $D_{2} O$ losses (Figure 13) is identical to the effect of the $\mathrm{D}_{2} \mathrm{O}$ interest rate. A one percent loss is equivalent to a one percent increase in interest rate. At lower interest rates, the losses would make up a larger fraction of the cost of the interest plus losses than at higher interest rates.

The minimum fuel cycle cost is less sensitive to the interest rate on non-fissile working capital (Figure 14), and more sensitive to the interest 
rate on the fuel inventory (Figure 15). As expected, lower enrichments are favored at higher fuel inventory interest rates. The effect of the combined interest rate on working capital and fuel inventory is shown in Figure 16.

Variations in $\mathrm{U}_{3} \mathrm{O}_{8}$ price have a significant effect on fuel cycle costs (Figure 17). The effect is nearly uniform for all three cases.

Similarly, the effect of variations in specific power is uniform for all three cases (Figure 18). Increasing specific power meets with diminishing returns. Beyond $20 \mathrm{kw} / \mathrm{kg}$, specific power has little influence on fuel cycle costs, and the advantages of further increases may be more than offset by increases in fuel fabrication costs.

In general within the range investigated for the parameters, the optimum enrichment varies from 1.0 to $1.5 \% \mathrm{U}^{235}$, the optimum exposure is between 18,000 and $22,000 \mathrm{MWD} / \mathrm{T}$, and the optimum lattice is a $\mathrm{D} / \mathrm{U}$ atom ratio between 20 and 40 . The Pickering $D / U$ ratio is 48 .

The conditions favoring higher $\mathrm{D} / \mathrm{U}$ ratios are low fabrication costs, high separative duty, low $\mathrm{D}_{2} \mathrm{O}$ costs, and low $\mathrm{D}_{2} \mathrm{O}$ interest rates. Lower interest rates on other parts of the fuei cycle tend to favor higher enrichments, exposures, and lower $D / U$ ratios.

In Table IV, the optimum lattice and enrichment and the corresponding fuel cycle cost is shown for several parametric values. As in Table $I$ each parameter is varied independently while the others remain at the base value. The relationship between enrichment and exposure for each lattice size is shown in Figure 19. 


\section{TABLE I}

\section{PARAMETRIC VALUES FOR BASE CASE}

$\underline{\text { Parameter }}$

$\mathrm{U}_{3} \mathrm{O}_{8}$

Specific Power

Reprocessing Cost

Fabrication Cost

All interest rates

Electrical Conversion Efficiency

$\mathrm{D}_{2} \mathrm{O}$ Cost

$\mathrm{D}_{2} \mathrm{O}$ Losses

Pressure Tube Thickness

$\mathrm{D}_{2} \mathrm{O}$ Purity

Separative Duty

Pu Value

Smeared Fuel Density
Value

$\$ 8 / 1 b$

$14.60 \mathrm{kw} / \mathrm{kg}$

$\$ 37 / \mathrm{kg}$

$\$ 30 / \mathrm{kg}$

$8 \%$

$29 \%$

$\$ 17.50 / 1 b$

$1 \%$

$0.19^{\prime \prime}$

$99.75 \%$

$\$ 26 / \mathrm{kg}$

$\$ 10 / g$ fissile

$10.0 \mathrm{~g} \mathrm{UO}_{2} / \mathrm{cc}$ 
EFFECT OF VARIOUS PARAMETERS ON FUEL CYCLE COSTS

\section{Parameter}

$\mathrm{U}_{3} \mathrm{O}_{8} \operatorname{Cos} \mathrm{t}$

Pú Price

Reprocessing Cost

Fabrication Cost

Interest Rate on Working Capltal and fuel inventory

Interest Rate

(F'uel inventory only)

Interest Rate

(Working capital on $\perp$ )

Flectrical Conversion Efficlency

Separative Duty

$\mathrm{D}_{2} \mathrm{O}$ Interest Rate

$\mathrm{D}_{2} \mathrm{O}$ Cost

$\mathrm{D}_{2} \mathrm{O}$ Losses

Pressure tube thickness

Corresponding Change in Fuel Cycle Cost, mills/kwhr

Increase or Decrease in

Parameter

\section{$\$ 1 / I b$ \\ $\$ 1 / \mathrm{g}$ \\ $\$ 5 / \mathrm{kg}$ \\ $\$ 5 / \mathrm{kg}$}

$1 \%$

$1 \%$

$2 \%$

$1 \%$

$\$ 10 / \mathrm{kg}$ of separative

work

$\begin{array}{cc}2 \% & .04 \\ \$ 1 / 1 b & .01 \\ 1 \% & .02 \\ .1 " & .11\end{array}$

.04
Optimum

Lattice \&

$\begin{array}{lll}\text { Natural } & \text { Optimum } & \text { Lattice \& } \\ \text { Enrichment } & \text { Enrichment } & \text { Enrichment }\end{array}$

.04

.04

$-.03$

.04

.04

.02

.01

.01

$-.03$

.05

.04

.04

.03

.01

.01

.05
Ratige

$\$ 4-\$ 12 / 1 b$

$\$ 5-\$ 20 / g$

$\$ 10-\$ 37 / \mathrm{kg}$

$\$ 15-\$ 45 / \mathrm{kg}$

$4 \%-12 \%$

$4 \%-8 \%$

$8 \%-12 \%$

$29 \%-34 \%$

$\$ 20-\$ 30 / \mathrm{kg}$

*No effect

$$
4 \%-12 \%
$$

$\$ 13.50-\$ 22.80 / 1 \mathrm{~b}$

$.5 \%-2.0 \%$

$.19^{\prime \prime}-.28 "$ 


\section{$\underline{\text { Parameter }}$}

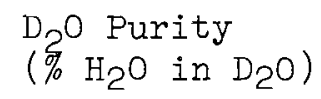

(b) Constant Fabrication Cost per unit Fuel Volume

Reactor Operating Cost

Reactor Capital Cost

( 30 year plant life)

Rate of Return on Capital.
(a) $4 \%$
(b) $8 \%$
(c) $12 \%$

TABLE II

(Continued)

Corresponding Change in Fuel Cycle Cost, mills/kwhr

Increase or Decrease in

Parameter

$1 \%$

$1 \mathrm{kw} / \mathrm{kg}$

10\% T.D.

10\% T.D.

$\$ 1,000,000 / \mathrm{yr}$

.17

.17

.17

$\$ 10 /$ kwe

.10

.10

.10

$\$ 10 / \mathrm{kwe}$

$\$ 10 /$ kwe
Optimum Lattice \&

Enrichment

Range

$100 \%-99 \% \mathrm{D}_{2} \mathrm{O}$ $7.3-21.9 \mathrm{kw} / \mathrm{kg}$ *not linear

73-91\% T.D. (Smeared fuel density)

73-91\% T.D. 
CHANGE IN EACH PARAMETER REQUIRED TO CAUSE

A $0.1 \mathrm{milI} / \mathrm{kwhr}$ CHANGE IN FUEL CYCLE COST

\begin{tabular}{|c|c|c|c|}
\hline Parameter & $\begin{array}{c}\text { Natural } \\
\text { Uranium } \\
\text { Enrichment } \\
\end{array}$ & $\begin{array}{l}\text { Optimum } \\
\text { Enrichment }\end{array}$ & $\begin{array}{l}\text { Optimum } \\
\text { Lattice \& } \\
\text { Enrichment } \\
\end{array}$ \\
\hline $\mathrm{U}_{3} \mathrm{O}_{8}$ Cost & $\$ 2.50 / 1 b$ & $\$ 2.50 / 1 \mathrm{~b}$ & $\$ 2.50 / \mathrm{lb}$ \\
\hline Pu Price & $\$ 2.50 / \mathrm{g}$ & $\$ 5 / g$ & $\$ 3.80 / \mathrm{g}$ \\
\hline Reprocessing Cost & $\$ 7 / \mathrm{kg}$ & $\$ 12.50 / \mathrm{kg}$ & $\$ 12.50 / \mathrm{kg}$ \\
\hline Fabrication Cost & $\$ 6 / \mathrm{kg}$ & $\$ 11.50 / \mathrm{kg}$ & $\$ 1 I .50 / \mathrm{kg}$ \\
\hline $\begin{array}{l}\text { Interest rate on Working } \\
\text { Capital and Fuel Inventory }\end{array}$ & $10 \%$ & $6 \%$ & $5 \%$ \\
\hline $\begin{array}{l}\text { Interest Rate } \\
\text { (Fuel Inventory Only) }\end{array}$ & $13 \%$ & $9 \%$ & $8 \%$ \\
\hline $\begin{array}{l}\text { Interest Rates } \\
\text { (Working Capital Only) }\end{array}$ & $40 \%$ & $20 \%$ & $20 \%$ \\
\hline $\begin{array}{l}\text { Electrical Conversion } \\
\text { Efficiency }\end{array}$ & $3.1 \%$ & $3.6 \%$ & $3.8 \%$ \\
\hline Separative Duty & * & $\$ 30 / \mathrm{kg}$ & $\$ 30 / \mathrm{kg}$ \\
\hline $\mathrm{D}_{2} \mathrm{O}$ Interest Rate & $4.4 \%$ & $4.4 \%$ & $6.7 \%$ \\
\hline $\mathrm{D}_{2} \mathrm{O}$ Cost & $\$ 10 / 1 b$ & $\$ 10 / 1 b$ & $\$ 13 / 1 b$ \\
\hline Pressure Tube Thickness & $.09^{\prime \prime}$ & $.45^{\prime \prime}$ & $.18 "$ \\
\hline $\mathrm{D}_{2} \mathrm{O}$ Purity & $0.45 \%$ & $1.7 \%$ & $0.91 \%$ \\
\hline
\end{tabular}

*No Effect 


\section{TABIE IV}

OPTIMUM LATTICE AND ENRICHMENT CALCULATED FOR

DIFFERENT VALUES OF SEVERAL IMPORTANT FUEL CYCLE COST PARAMETERS

\section{Parameter Value}

Base Case

Specific Power@ $9.3 \mathrm{kw} / \mathrm{kg}$

Specific Power @ $10.9 \mathrm{kw} / \mathrm{kg}$

Specific Power@ @ $18.2 \mathrm{kw} / \mathrm{kg}$

Specific Power @ $21.9 \mathrm{kw} / \mathrm{kg}$

$\mathrm{U}_{3} \mathrm{O}_{8} @ \$ 4 / \mathrm{Ib}$

$\mathrm{U}_{3} \mathrm{O}_{8} @ \$ 12 / \mathrm{Ib}$

Plutonium @ \$20/g fissile

Plutonium @ \$15/g fissile

Plutonium@\$5/g fissile

Reprocessing cost @ $\$ 20 / \mathrm{kg} \mathrm{U}$

Reprocessing Cost@ $\$ 10 / \mathrm{kg} \mathrm{U}$

Fabrication Cost@ \$45/kg U

Fabrication Cost@ @ $15 / \mathrm{kg}$ U

Interest Rates on Working Capital

and Fuel Inventory @ 4\%

Interest Rates on Working Capital

and Fuel Inventory @ 12\%

Interest Rate@12\%

(Working Capital Only)

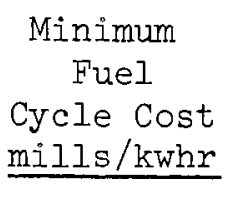

0.88

1.12

0.97

0.83

0.80

0.68

1.05

0.62

0.76

0.89

0.77

0.69

0.99

0.75

0.80

1.00

0.91

0.82
Optimum

Lattice

$D / U$ atom

Ratio

31

\begin{tabular}{l} 
Optimum \\
Enrichment \\
$\%$ U-235 \\
\hline
\end{tabular}

1.23

$20 *$

1.33

$20 *$

1.40

32

1.27

32

1.30

26

1.40

34

1.16

$20 *$

1.20

31

1.05

36

1.13

34

1.01

35

0.92

28

1.36

34

1.05

23

1.51

40

1.02

37

1.08

Electrical Conversion

Efficiency@31.5

40

1.10 
TABLE IV

(Continued)

\section{Parameter Value}

Electrical Conversion

Efficiency@ 34.0

Separative Duty @ $\$ 20 / \mathrm{kg}$

Separative Duty @ $\$ 30 / \mathrm{kg}$

$\mathrm{D}_{2} \mathrm{O}$ Interest Rate @ $4 \%$

$\mathrm{D}_{2} \mathrm{O}$ Interest Rate @ $12 \%$

$\mathrm{D}_{2} \mathrm{O}$ Cost @ \$13.50/1b

$\mathrm{D}_{2} \mathrm{O}$ Cost @ \$22.80/1b

$\mathrm{D}_{2} \mathrm{O}$ Losses @ $1.2 \%$

$\mathrm{D}_{2} \mathrm{O}$ Losses @ 2.0\%

\begin{tabular}{l} 
Minimum \\
Fuel \\
Cycle Cost \\
mills/kwhr \\
\hline
\end{tabular}

Optimum

Lattice

$\mathrm{D} / \mathrm{U}$ atom

Ratio

0.76

0.86

0.91

0.82

0.94

0.86

0.93

0.88

0.90
40

1.09

20

1.57

40

1.06

40

$20 *$

36

$20 *$

31

29

1.53

1.15

1.53

1.23

1.30
Optimum Enrichment

$\% \mathrm{U}-235$

*Lowest moderator to fuel ratio investigated. The minimum fuel cycle cost occurs below this point. 


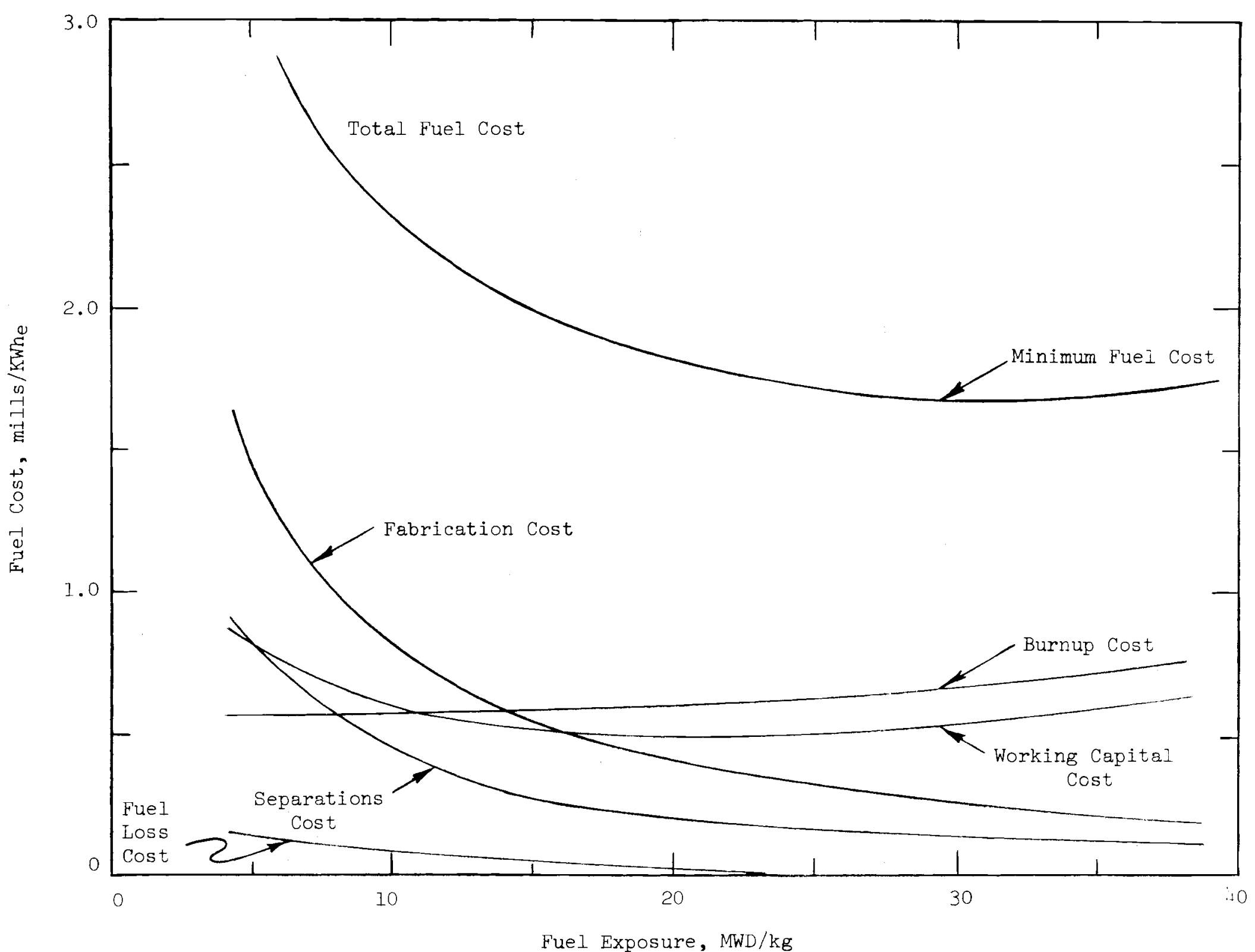

Figure 1 TYPICAL FUEL COST DATA AS A FUNCTION OF FUEL EXPOSURE 


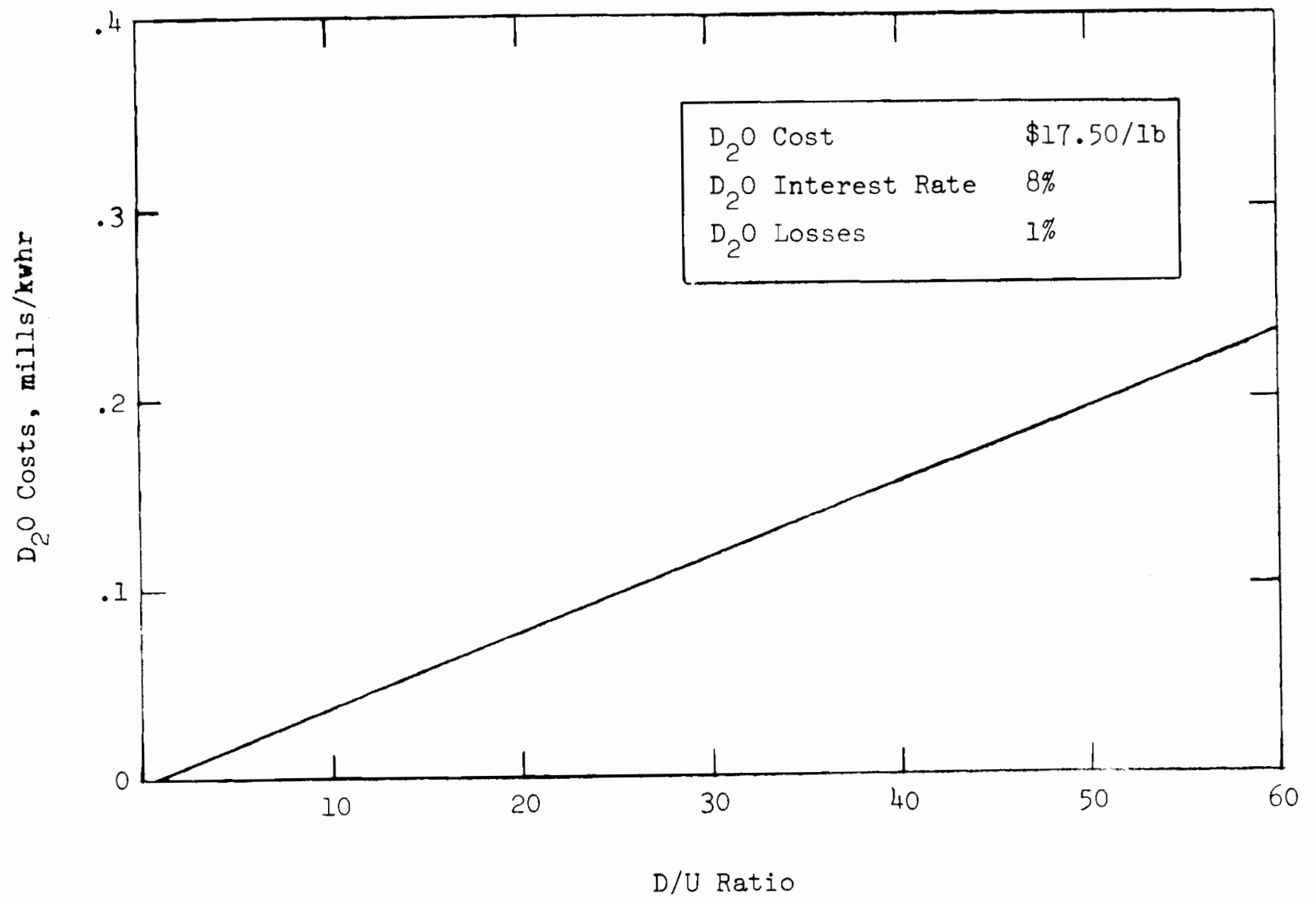

Figure 2 EFFECT OF LATTICE SIZE ON $\mathrm{D}_{2} \mathrm{O}$ COSTS 


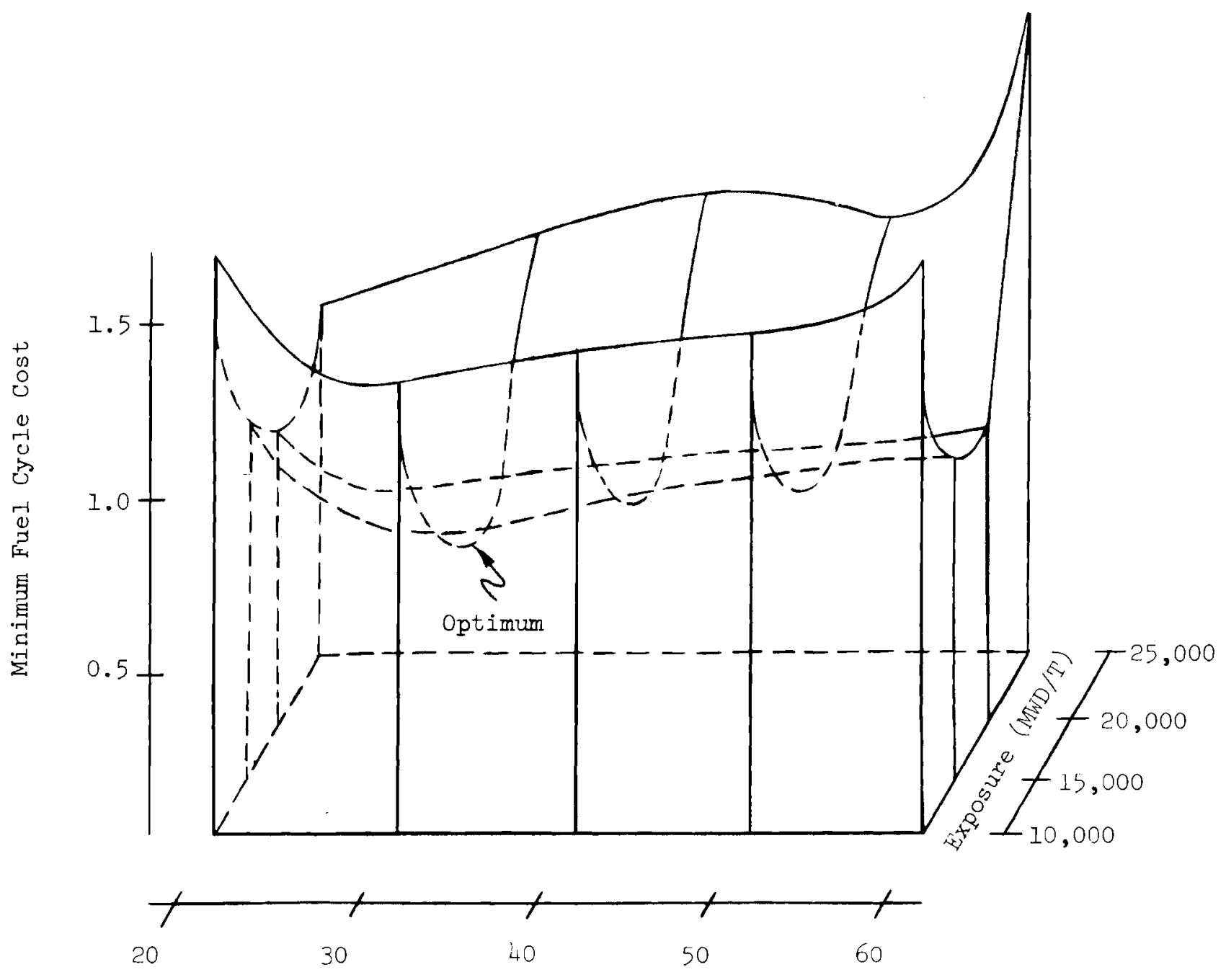

Moderator to Fuel ( $D / U$ atom) Ratio

Figure 3 OPTIMIZATION OF MODERATOR TO FUEL RATIO AND FUEL EXPOSURE 


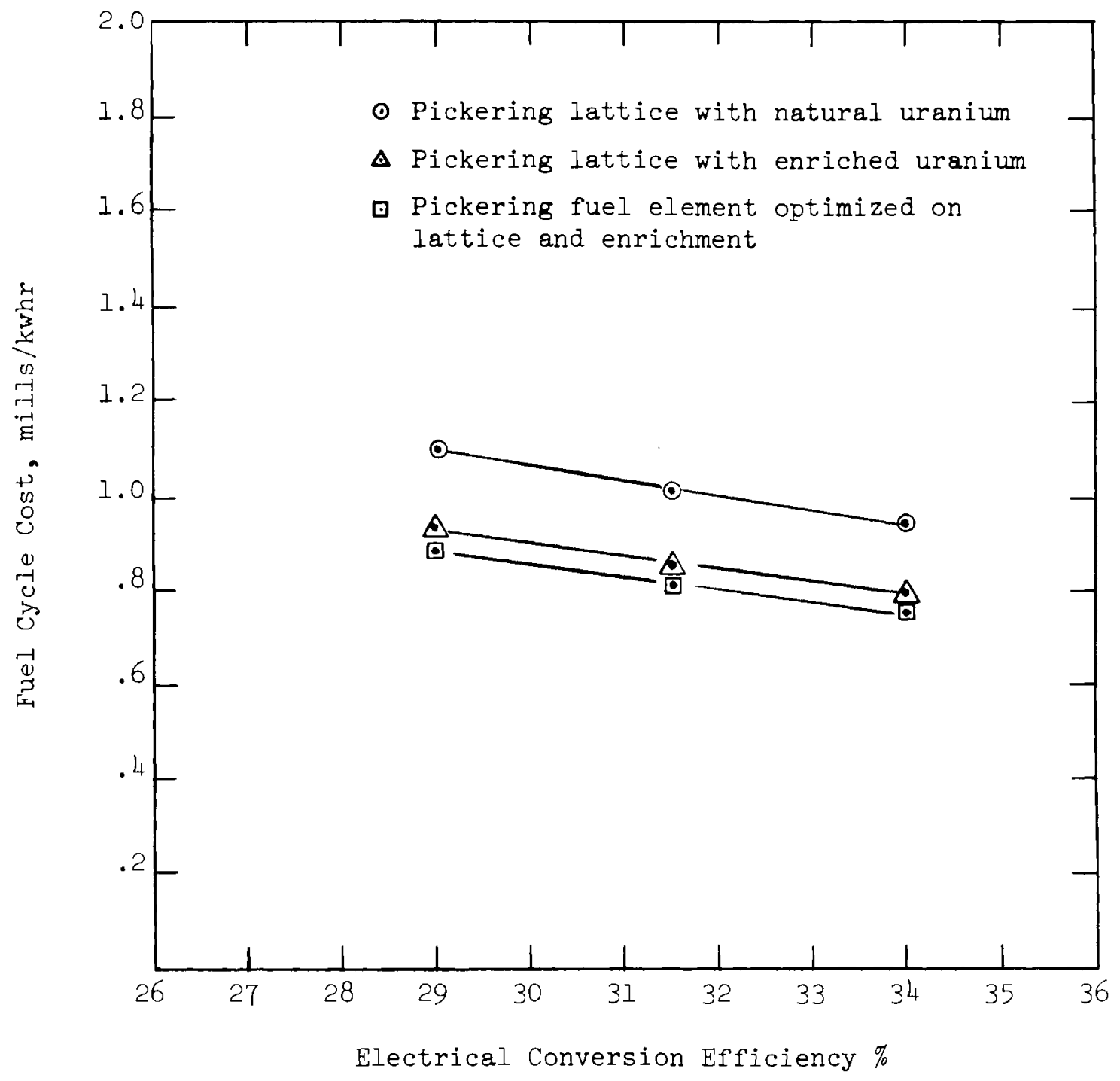

Figure 4 EFFECT OF ELECTRICAL CONVERSION EFFICIENCY ON FUEL CYCLE COST 


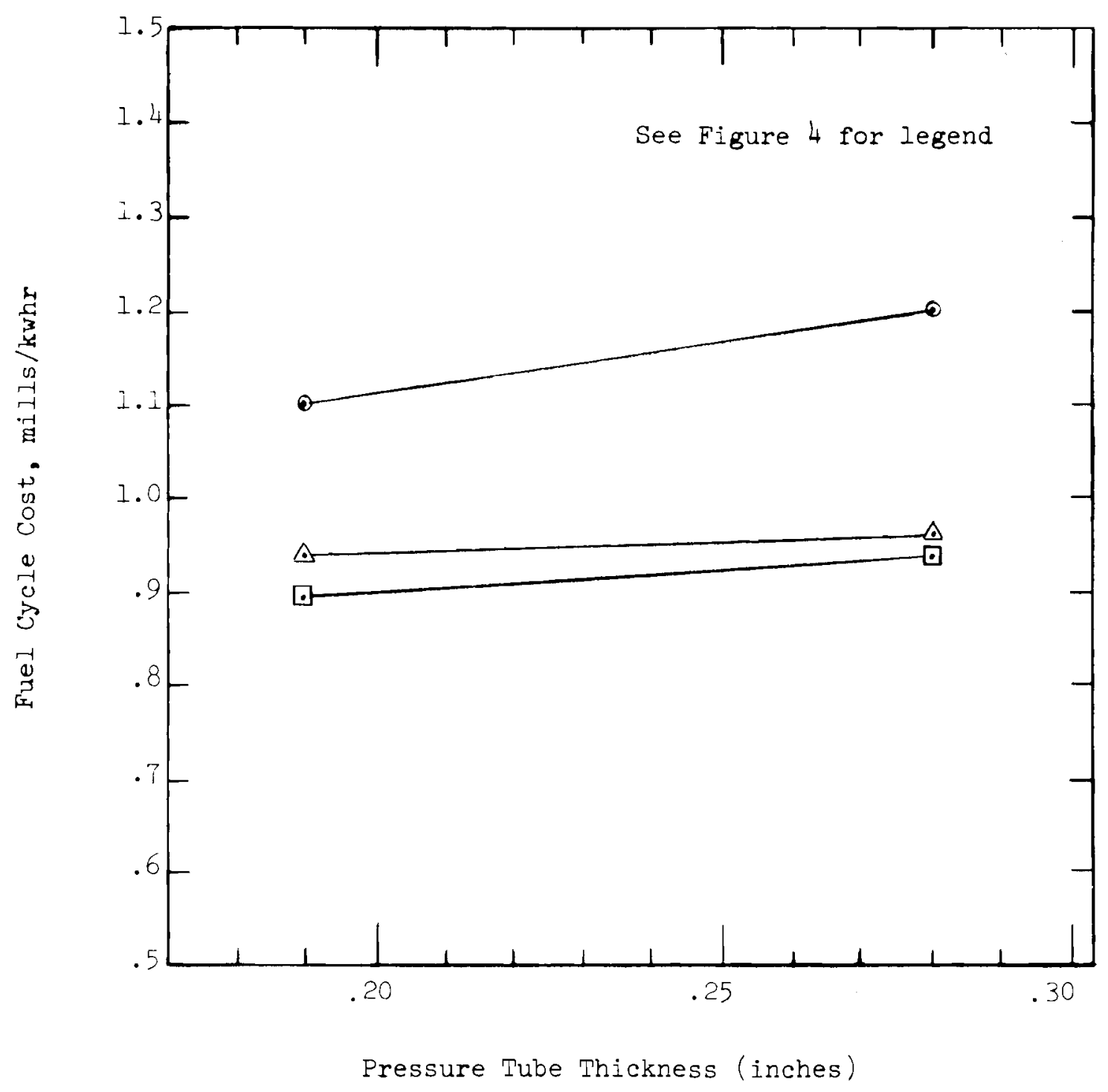

Figure 5 EFFECT OF PRESSURE TUBE THICKNESS ON FUEL CYCLE COST 


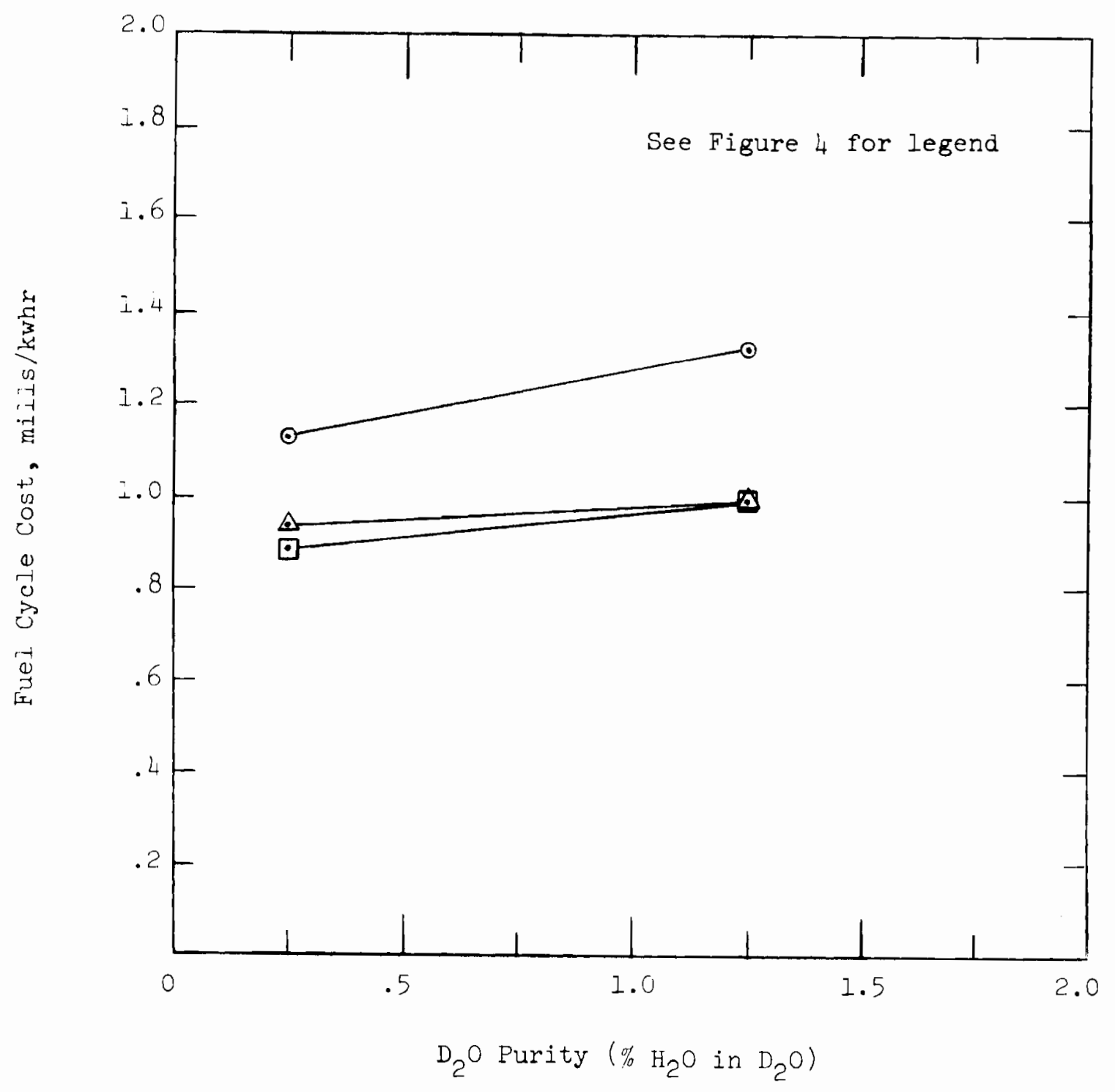

Figure 6 EFFECT OF $D_{2} \mathrm{O}$ PURITY ON FUEL CYCLE COST 


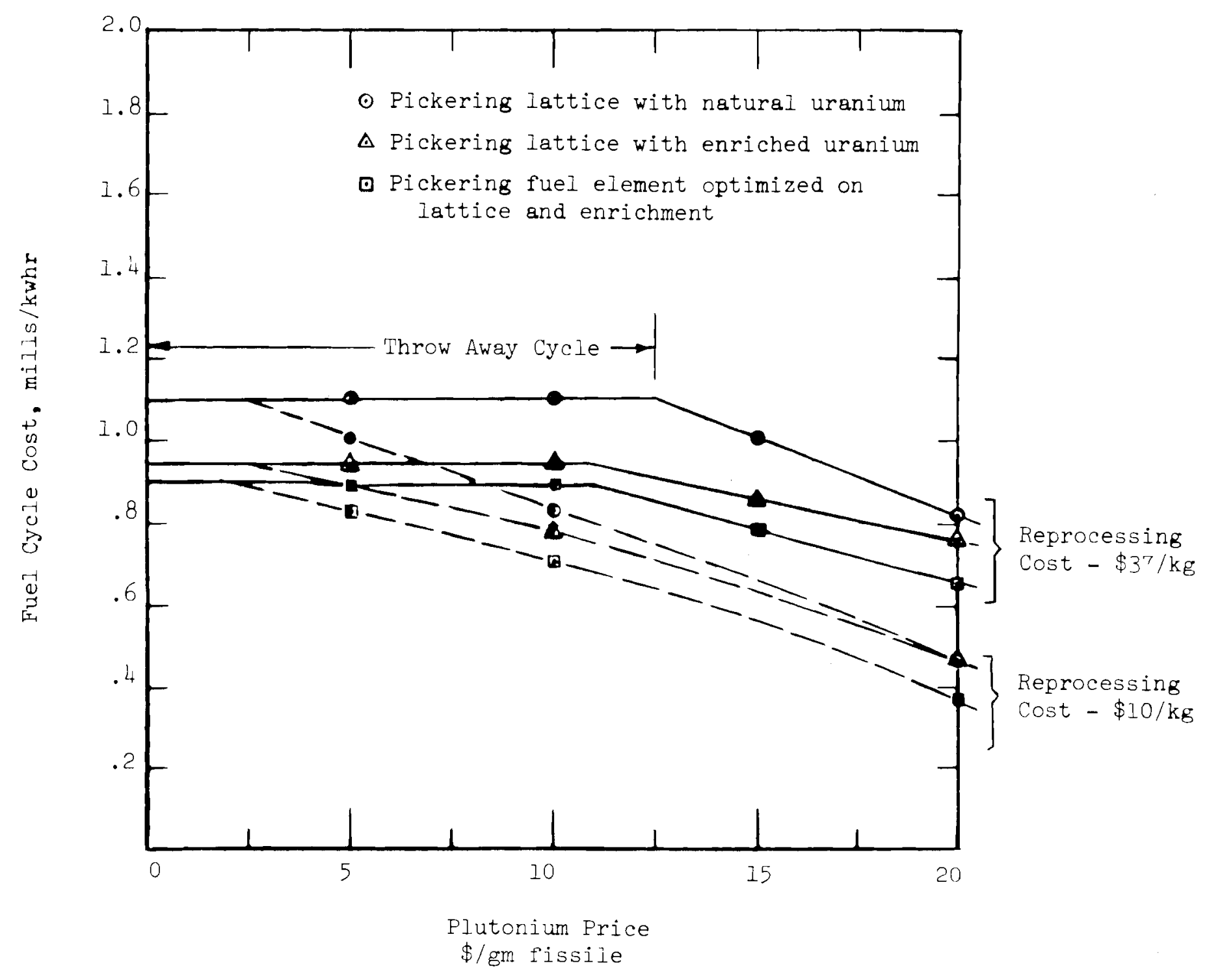

Figure 7 EFFECT OF PLUTONIUM PRICE ON FUEL CYCLE

COST FOR TWO REPROCESSING COSTS 


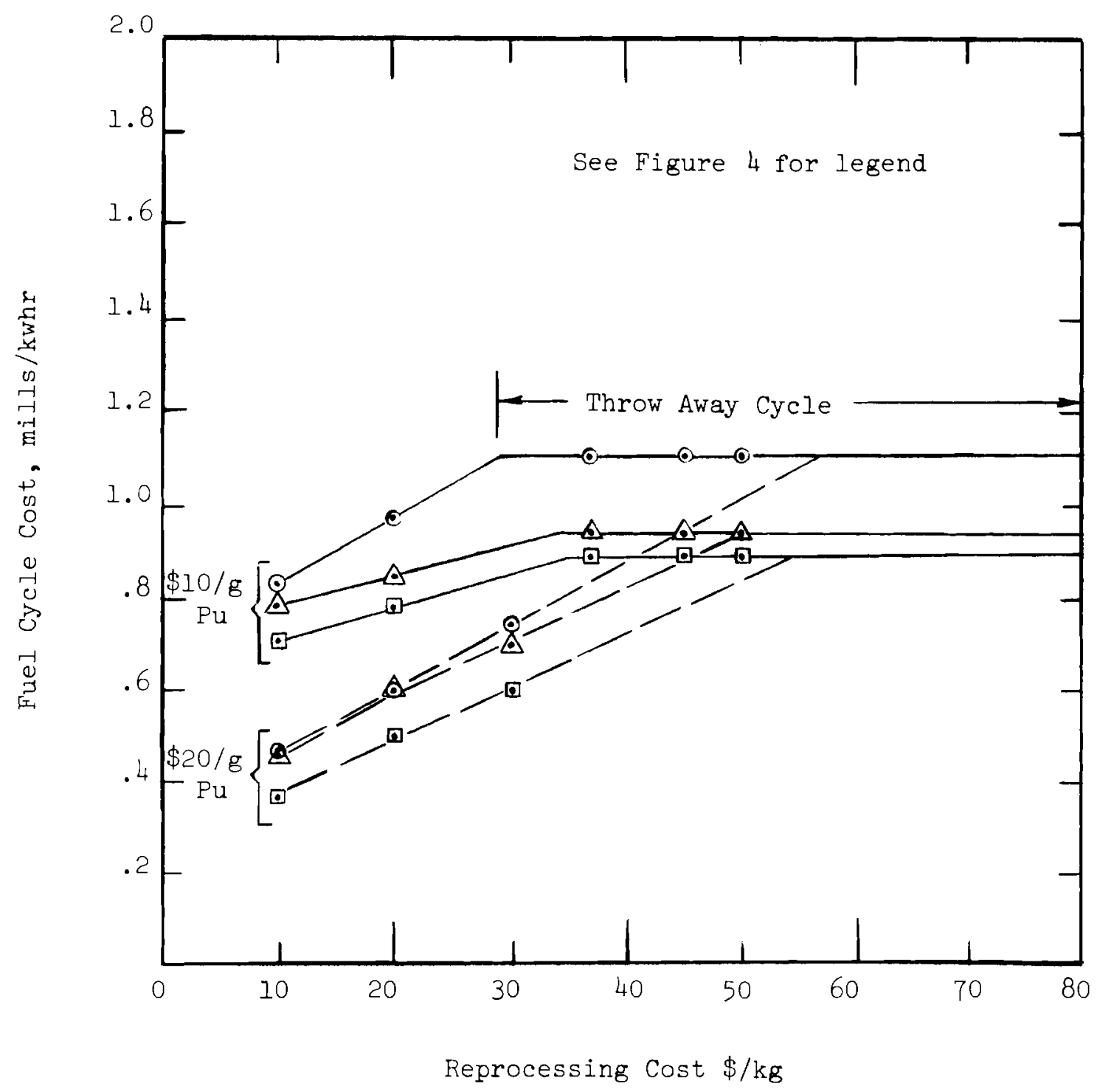

Figure 8 EFFECT OF REPROCESSING COST ON

FUEL CYCLE COST FOR TWO PLUTONIUM PRICES 


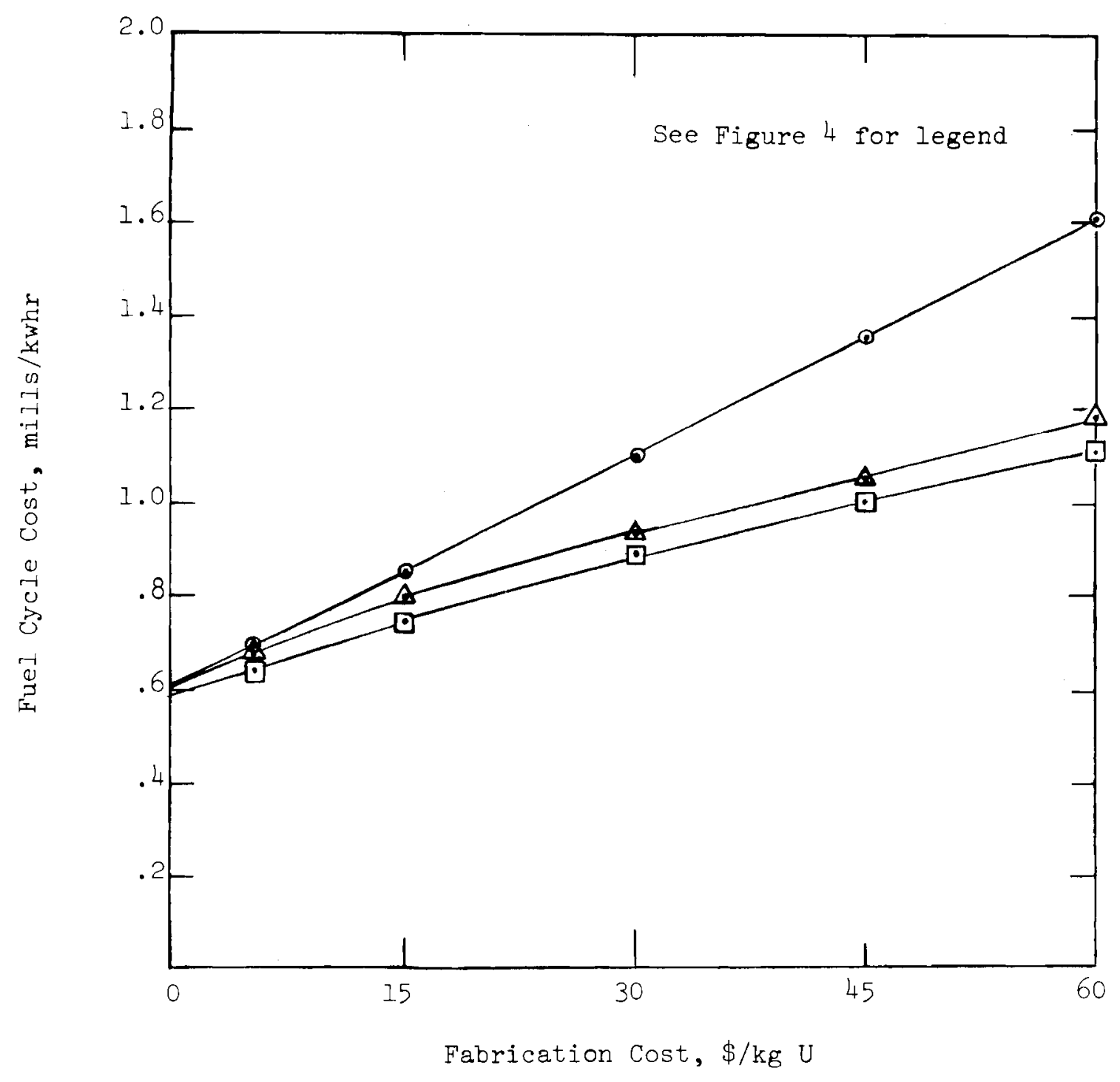

Figure 9 EFFECT OF FABRICATION COST ON FUEL CYCLE COST 


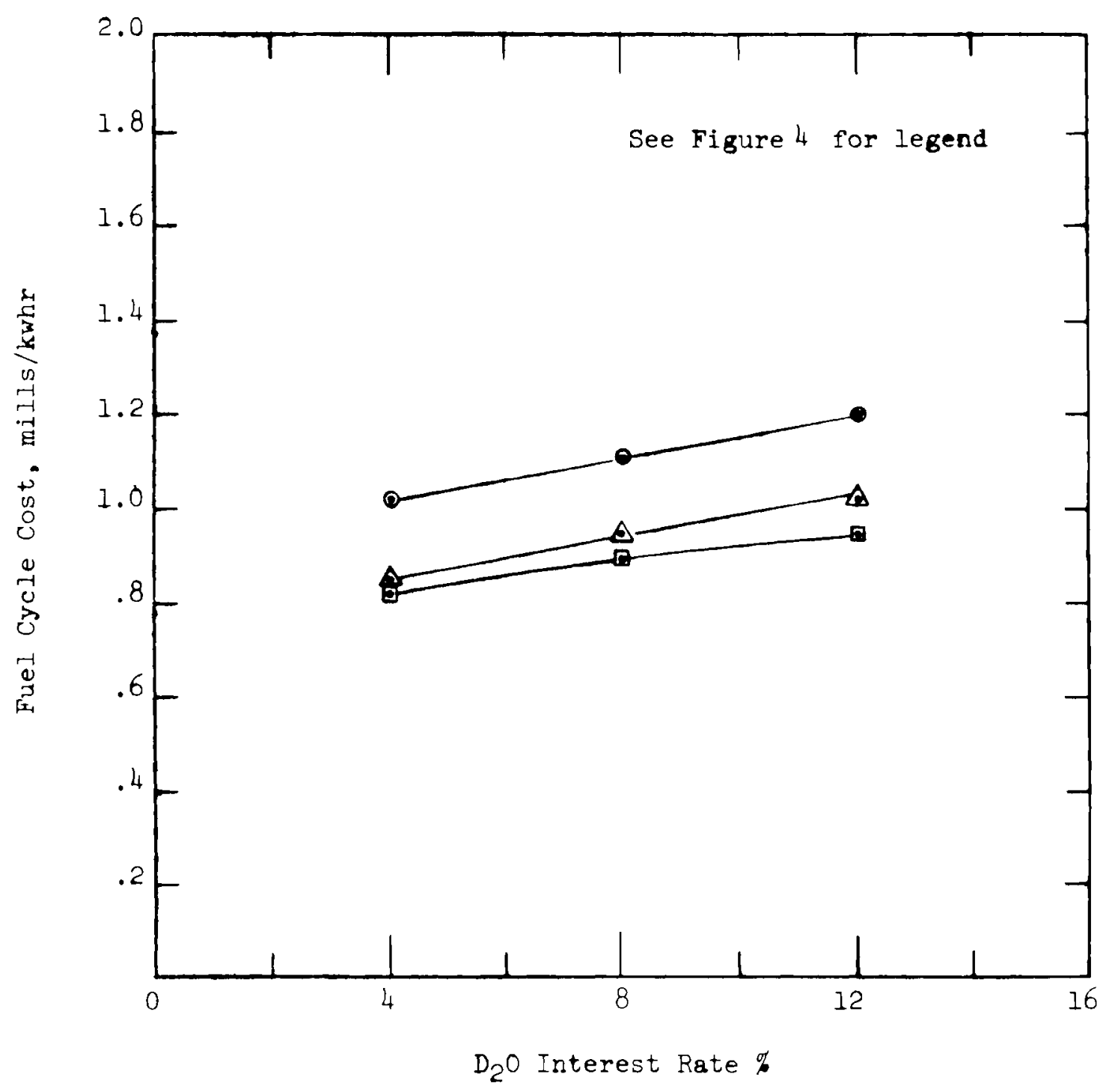

Figure 10 EFFECT OF $D_{2} O$ INTEREST RATE ON FUEL CYCLE COST 


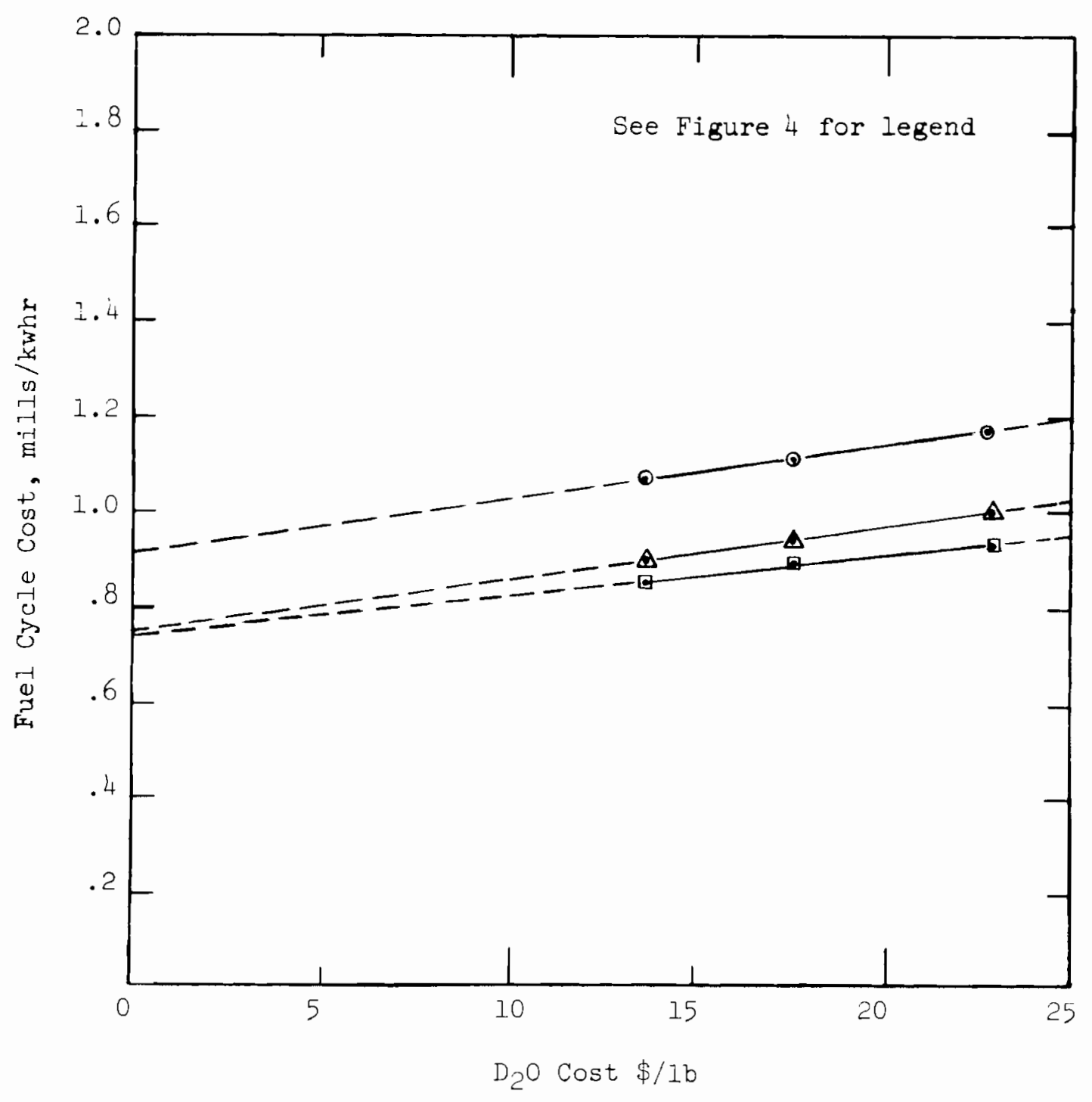

Figure 11 EFFECT OF D $\mathrm{D}_{2}$ COST ON FUEL CYCLE COST 


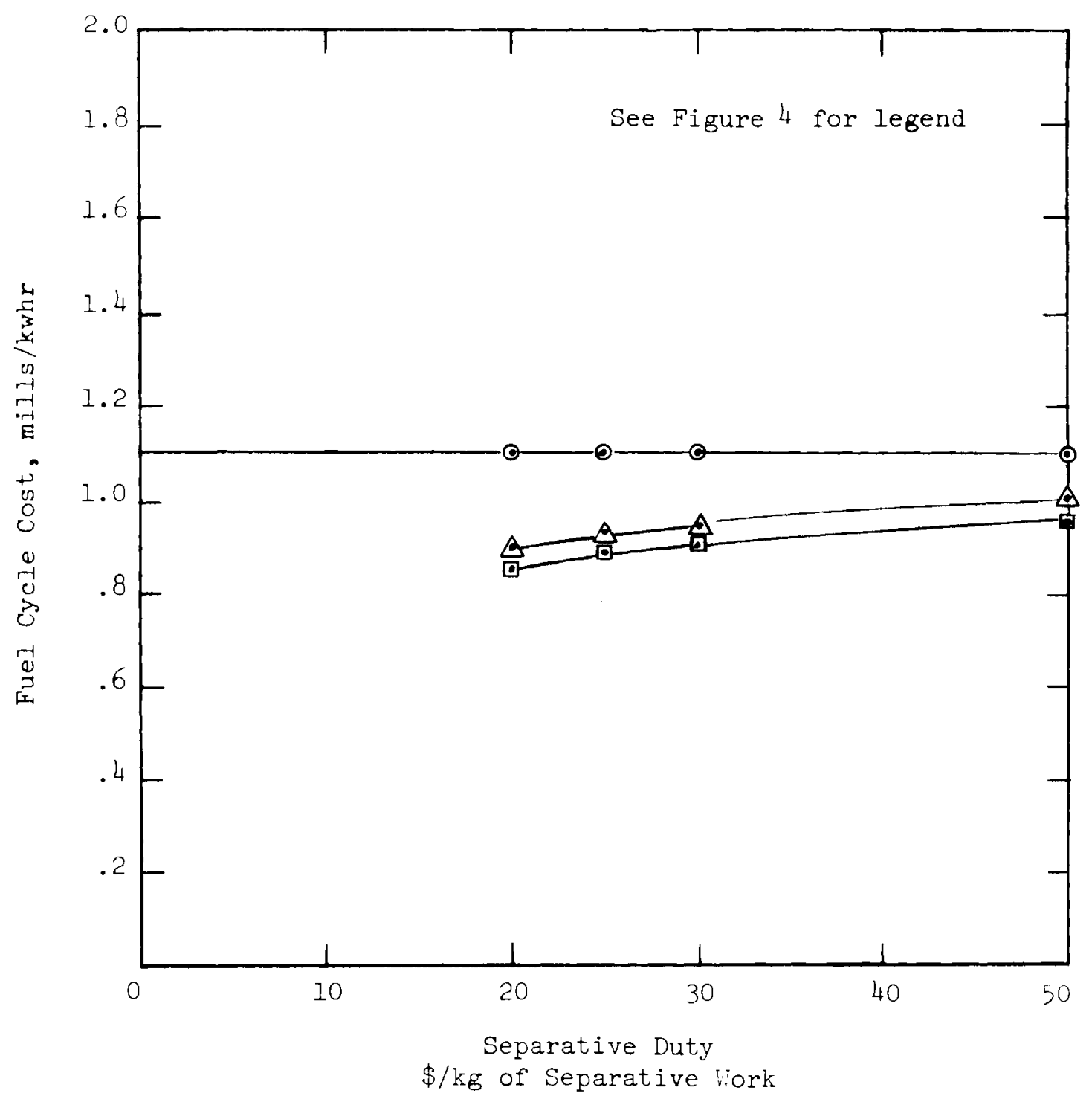

Figure 12 EFFECT OF SEPARATIVE DUTY ON FUEL CYCLE COST 


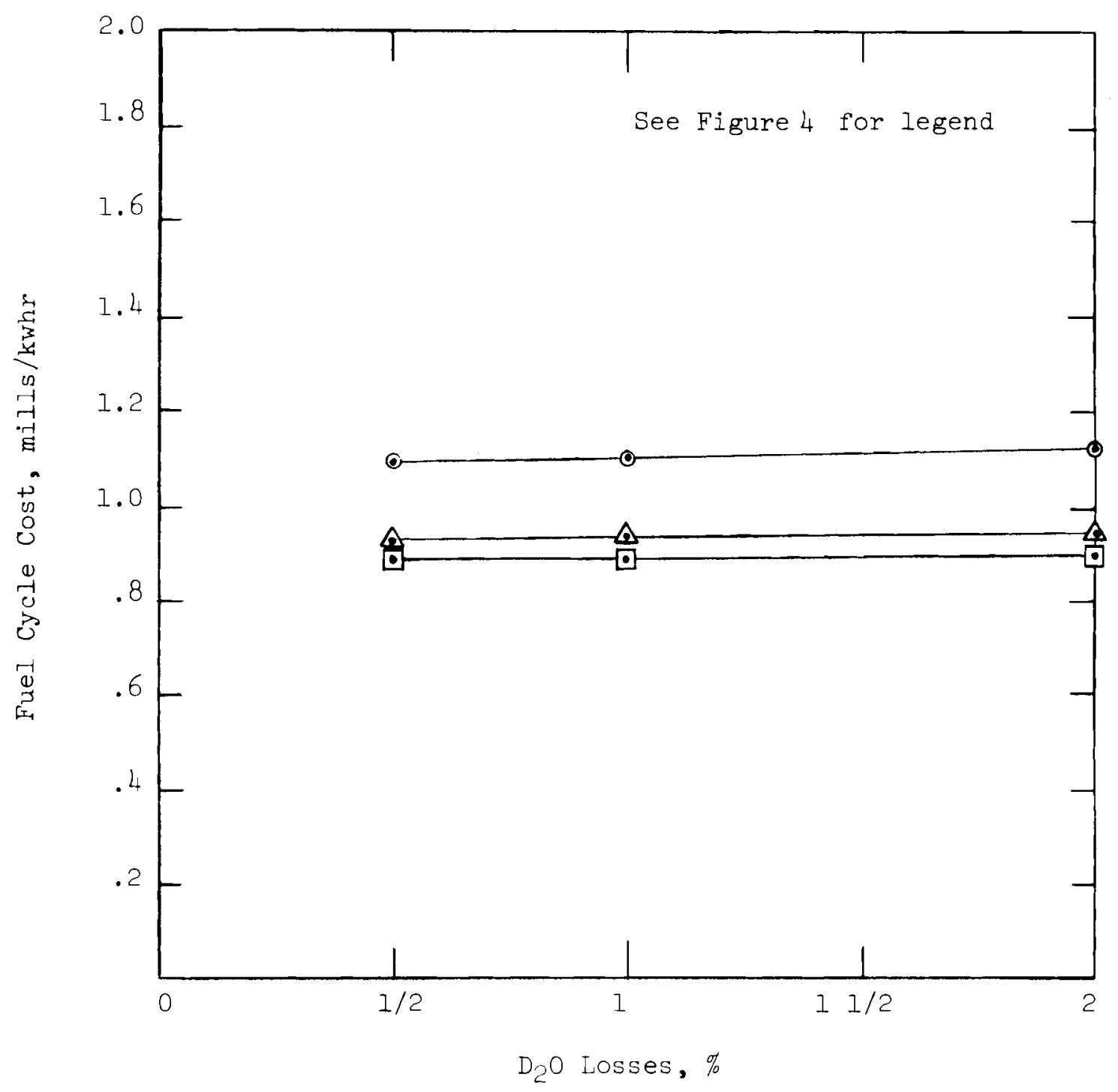

Figure 13 EFFECT OF $D_{2} \mathrm{O}$ LOSSES ON FUEL CYCLE COST 


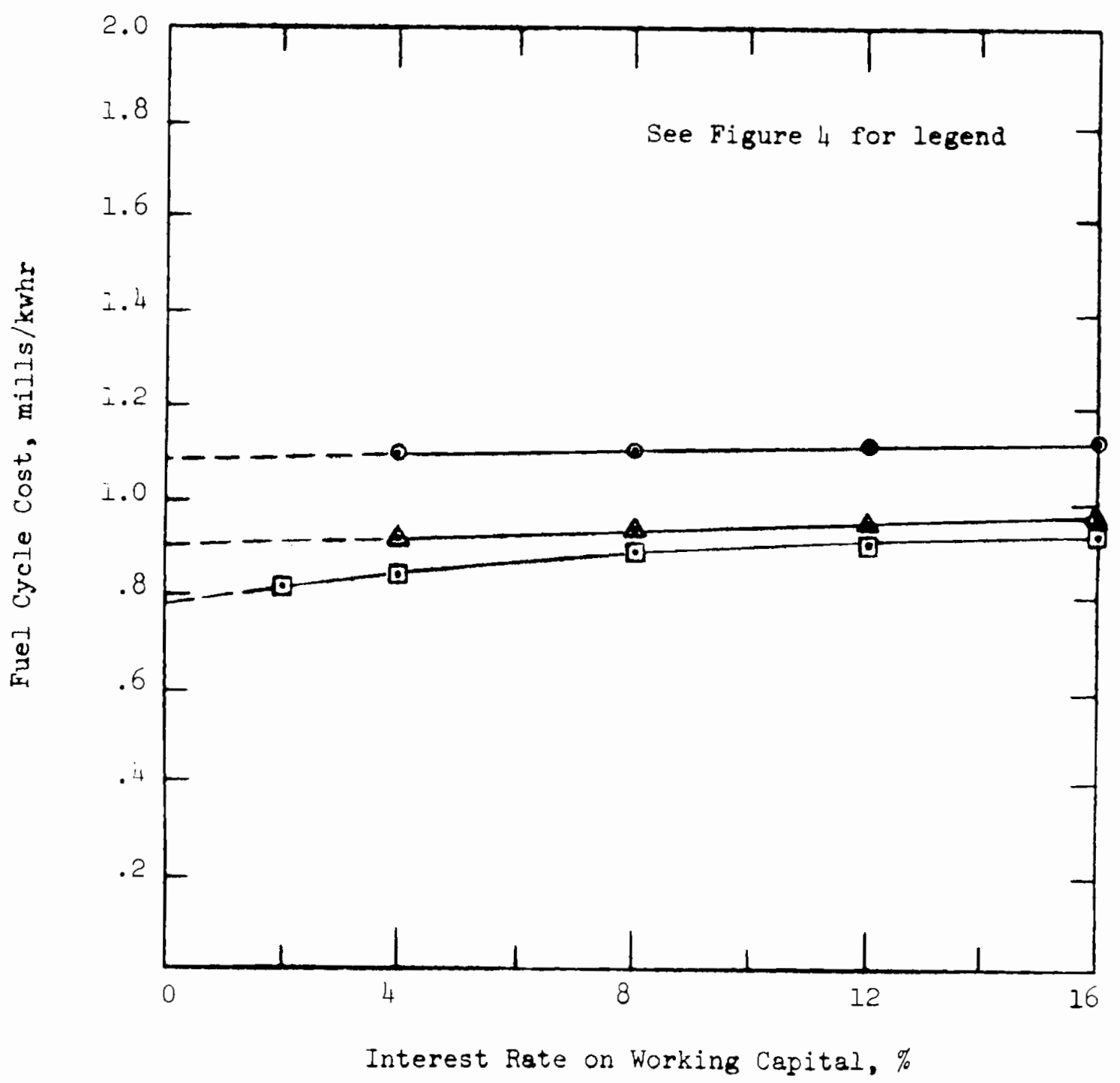

Figure 14 EFFECT OF WORKING CAPITAL INTEREST RATES ON FUEL CYCLE COST 


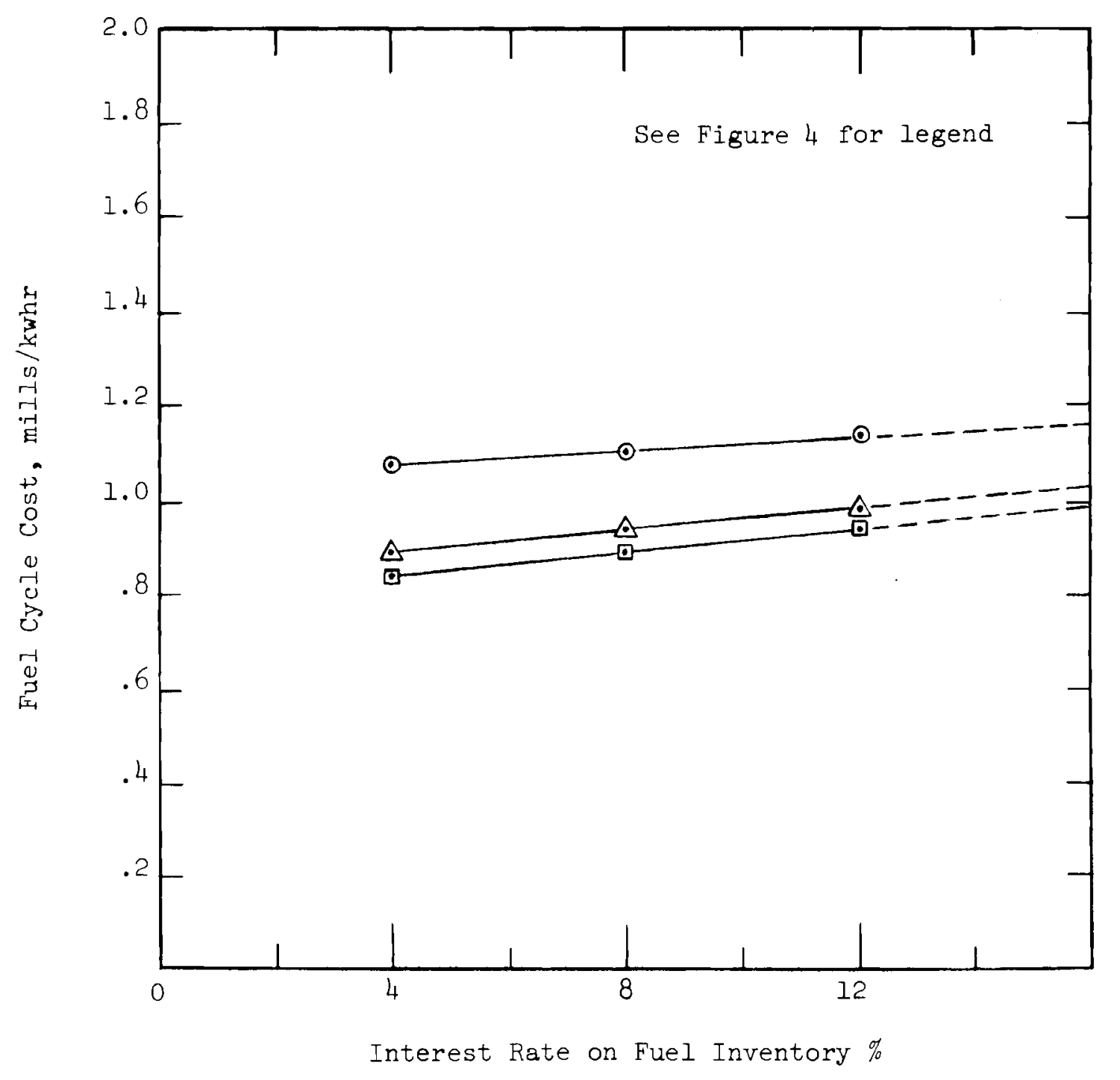

Figure 15 EFFECT OF FUEL INVENTORY INTEREST RATE ON FUEL CYCLE COSTS 


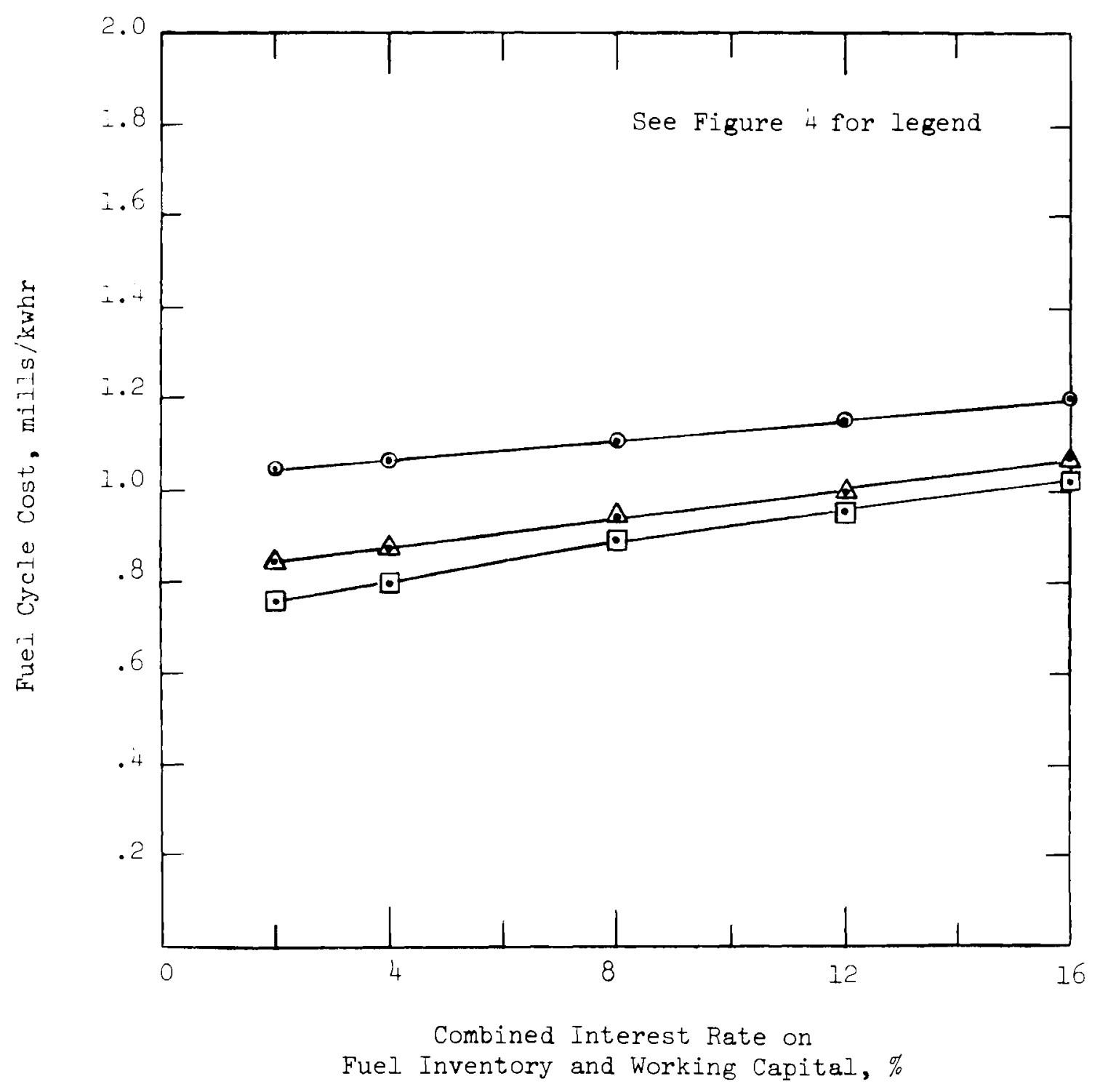

Figure 16 COMBINED EFFECT OF INTEREST RATES ON FUEL CYCLE COSTS 


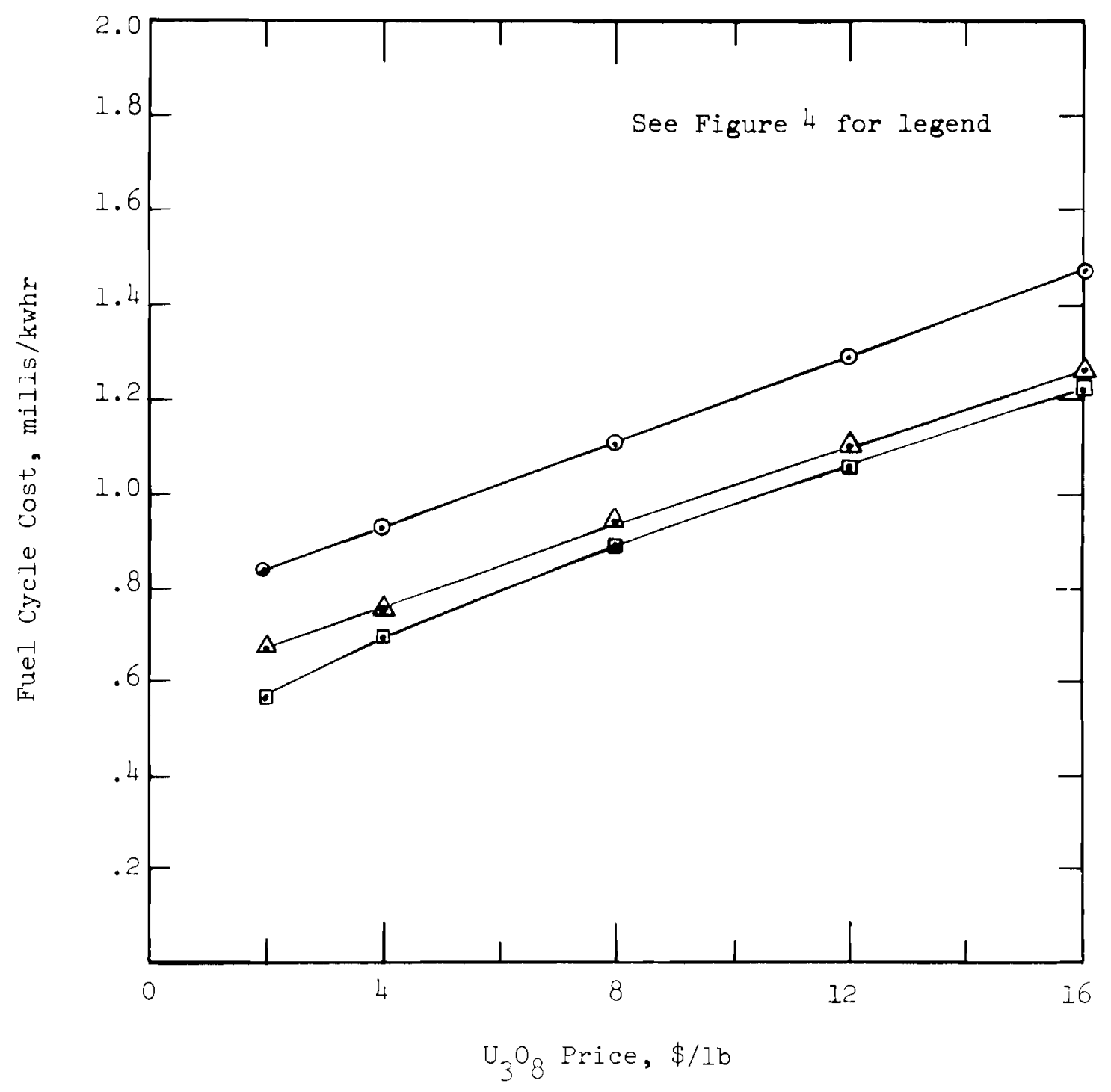

Figure 17 EFFECT OF $\mathrm{U}_{3} \mathrm{O}_{8}$ PRICE ON FUEL CYCLE COST 


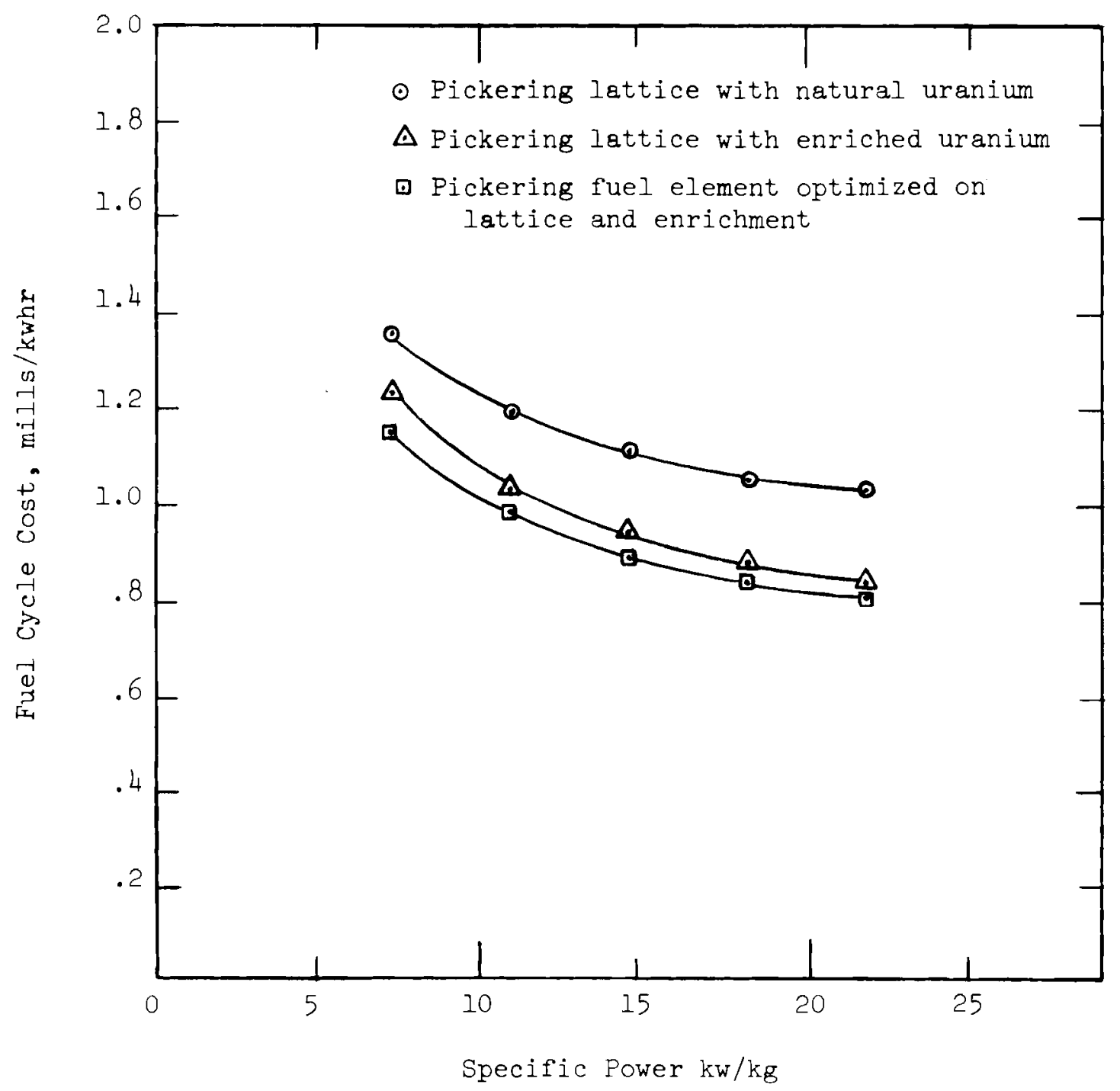

Figure 18 EFFECT OF SPECIFIC POWER ON FUEL CYCLE COST 


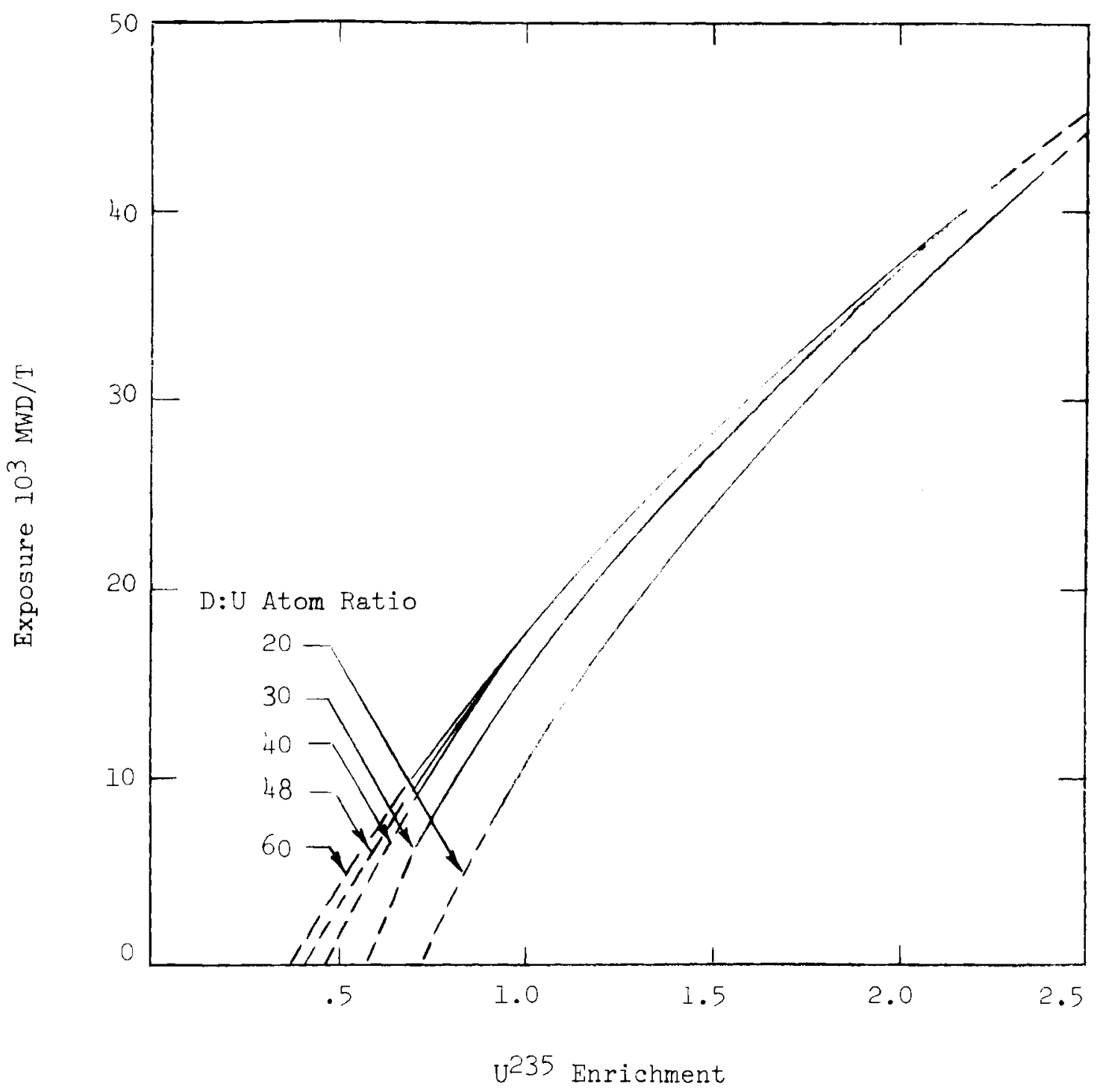

Figure 19 RELATIONSHIP BETWEEN ENRICHMENT AND EXPOSURE FOR FIVE MODERATOR TO FUEL RATIOS 


\section{$\underline{\text { REFERENCES }}$}

1. Halsall, M. J., "Graphs and Tables of the Isotopic Composition of Plutonium Produced in Canadian $\mathrm{D}_{2} \mathrm{O}$ Cooled and Moderated Reactors, AECL-2631, October, 1966.

2. E. A. Eschbach, D. E. Deonigi, E. T. Merrill, and W. I. Neef, "A System of Chained Computer Codes for Reactor Fuel Cycle Analysis," Proc. Conf. Application of Computing Methods to Reactor Problems, (May 1965). ANL-7050, Argonne National Lab., pp. 327-345 (August $1965)$.

3. E. A. Eschbach, D. E. Deonigi, and A. F. McConiga, "MINIMIZER - A Computer Code for Determining Minimum Fuel Cost," HW-71813, Hanford Works (July 1965). 


\section{DISTRIBUTION}

Number of Copies 268

AEC Division of Technical Information Extension

1

AEC Chicago Patent Group

R. K. Sharp

2

AEC RDT Representative - PNL

P. G. Holsted

2

AEC Richland Operations Office

C. L. Robinson

Technical Information Library

Fast Reactor Exchange

US/UK (12)

US/Euratom (35)

Battelle-Northwest

F. W. Albaugh

J. M. Batch

C. A. Bennett (2)

C. H. Bloomster (20)

J. G. Bradley

J. B. Burnham

G. J. Busselman

S. H. Bush

G. M. Dalen

F. G. Dawson, Jr.

D. R. deHalas

D. E. Deonigi

E. A. Eschbach

E. A. Evans

J. R. Fishbaugher

J. C. Fox

S. Golds mith

D. R. Haffner

W. L. Hampson

H. Harty

P. A. Horton

D. D. Lanning

B. B. Lane

G. A. Last (10)

W. R. Lewis

L. G. Merker

E. T. Merrill

R. W. McKee 
J. H. Nail

S. E. Nunn

W. W. Porath (5)

R. G. Rau

W. A. Reardon

R. L. Reynolds

L. C. Schmid

E. A. Schnaible

R. E. Shaver

R. E. Shippert

R. I. Smith

J. R. Worden

J. R. Young

Technical Information Files (5) 